\title{
ANNOUNCEMENTS
}

\section{YUGOSLAVIA APPLIES TO THE INTERNATIONAL COURT OF JUSTICE IN A DISPUTE WITH THE MEMBER STATES OF NATO IN RESPECT OF THE THREAT OF USE OF FORCE BY NATO}

The following information has been made available by the Registry of the International Court of Justice (Communiqué No. 94/11, 21 March 1994):

On 16 March 1994 the Chargé d'Affaires of the Federal Republic of Yugoslavia to the Netherlands presented at the International Court of Justice an Application against the Member States of NATO, claiming that by the adoption of the decisions taken at a meeting of the North Atlantic Council on 9 February 1994, the Member States have breached Articles 2(4) and 53(1) of the United Nations Charter, by 'threatening to use force without the authorization of the Security Council and in the form of an ultimatum'.

In that document the Yugoslav Government bases the jurisdiction of the Court on the Statute of the Court and 'consent given by the respondent States in accordance with Article 38(5) of the Rules of Court'.

Article 38, paragraph 5, of the Rules of Court reads as follows:

'When the applicant State proposes to found the jurisdiction of the court upon a consent thereto yet to be given or manifested by the State against which such application is made, the application shall be transmitted to that State. It shall not however be entered in the General List, nor any action be taken in the proceedings, unless and until the State against which such application is made consents to the Court's jurisdiction for the purposes of the case.'

In accordance with the provisions of that Article, the Registry, which has not yet entered that Application in the Court's General List, has nonetheless transmitted it to the Governments of the Member States of NATO. 


\section{THE PAUL GUGGENHEIM PRIZE 1995}

The Board of the Paul Guggenheim Foundation has decided to award the eighth Paul Guggenheim Prize of 12,000 Swiss francs in 1995.

The Paul Guggenheim Prize is periodically awarded to a monograph of major importance in the field of public international law. The monograph must be of the highest quality and be the work of a person at the beginning of his/her career. Works submitted may be in the form of published books or of manuscripts intended for publication: they may be written in English, French, German, Italian or Spanish. Works which have already received a prize of a similar nature will not be considered.

Applications accompanied by a curriculum vitae, a list of publications and five copies of the work submitted must be received, no later than 31 January 1995 by the Paul Guggenheim Foundation, The Graduate Institute of International Studies, 132, rue de Lausanne, 1211 Genève 21 (Switzerland). Applicants are required to specify whether the work has already been awarded a prize.

The Rules pertaining to the Prize may be obtained at the same address. 